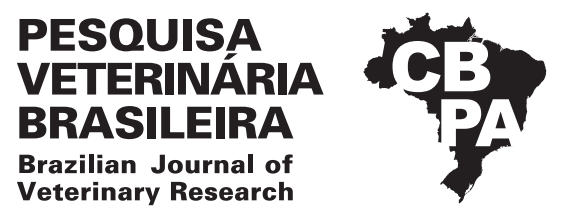

Pesq. Vet. Bras. 38(9):1752-1760, setembro 2018 DOI: 10.1590/1678-5150-PVB-5768

Original Article

Animais de Produção/Livestock Diseases

ISSN 0100-736X (Print)

ISSN 1678-5150 (Online)

\title{
Neurological diseases of cattle in the state of Goiás, Brazil (2010-2017)
}

\author{
Juliano P. Terra² ${ }^{2}$ Guilherme R. Blume ${ }^{3}$, Rogério E. Rabelo ${ }^{4}$, \\ Jussara T. Medeiros ${ }^{5}$, Caio G.N. Rocha ${ }^{6}$, Imara N. Chagas ${ }^{7}$, Marília da S. Aguiar \\ and Fabiano J.F. de Sant'Ana ${ }^{7 *}$
}

\begin{abstract}
Terra J.P., Blume G.R., Rabelo R.E., Medeiros J.T., Rocha C.G.N., Chagas I.N., Aguiar M.S. \& Sant'Ana F.J.F. 2018. Neurological diseases of cattle in the State of Goiás, Brazil (2010-2017). Pesquisa Veterinária Brasileira 38(9):1752-1760. Laboratório de Diagnóstico Patológico Veterinário, Universidade de Brasília, Brasília, DF 70910-900, Brazil. E-mail: santanafjf@yahoo.com

A retrospective study was conducted on neurological diseases of cattle in the state of Goiás, Brazil, from March 2010 to August 2017. Samples of three veterinary diagnostic laboratories were analyzed. Diagnosis was established in 170 out of 407 cattle with neurological signs. Epidemiological, clinical, and anatomic pathology features of each case were researched in the files. Main disorders included diseases caused by viruses (rabies $29.41 \%$, meningoencephalitis by bovine herpesvirus $15.88 \%$, and malignant catarrhal fever $1.76 \%$ ), by bacteria (botulism $5.88 \%$, suppurative meningitis $3.53 \%$, encephalic abscesses $2.94 \%$, listeriosis $1.76 \%$, and thrombotic meningoencephalitis 1.76\%), of metabolic origin (polioencephalomalacia 17.06\%), of indefinite cause (lymphoplasmacytic meningoencephalitis 11.18\%, traumatic hemorrhages $3.53 \%$, and multifocal malacia with gliosis $1.18 \%$ ), congenital (hydrocephaly $1.18 \%$ and multiple malformations $0.59 \%$ ), toxic (urea poisoning $1.18 \%$ and insecticide poisoning $0.59 \%$ ), and parasitic (meningoencephalitis associated with infection by Trypanosoma sp. $0.59 \%$ ).
\end{abstract}

INDEX TERMS: Neurological diseases, Goiás, diseases of cattle, neuropathology, rabies, polioencephalomalacia, bovine herpesvirus, neurology, pathology.

RESUMO.- [Doenças neurológicas de bovinos no estado de Goiás (2010-2017).] Foi realizado um estudo retrospectivo de doenças neurológicas de bovinos no estado de Goiás durante

\footnotetext{
${ }^{1}$ Received on February 21, 2018.

Accepted for publication on March 20, 2018.

${ }^{2}$ Programa de Pós-Graduação em Ciência Animal, Universidade Federal de Goiás (UFG), Campus Samambaia, Av. Esperança s/n, Chácaras de Recreio Samambaia, Goiânia, GO 74690-900, Brazil.

${ }^{3}$ Programa de Pós-Graduação em Saúde Animal, Laboratório de Diagnóstico Patológico Veterinário (LDPV), Hospital Veterinário de Grandes Animais, Universidade de Brasília (UnB), SRB, Área Especial, Galpão 4, Granja do Torto, Brasília, DF 70636-020, Brazil.

${ }^{4}$ Universidade Federal de Goiás (UFG), Regional Jataí, BR-364, Km 192, Jataí, GO 75804-020, Brazil.

${ }^{5}$ Acadêmica de Medicina Veterinária, Laboratório de Diagnóstico Patológico Veterinário (LDPV), Universidade de Brasília (UnB), Brasília, DF 70636-020.

${ }^{6}$ Laboratório de Análise e Diagnóstico Veterinário (Labvet), Agência Goiana de Defesa Agropecuária (Agrodefesa), Rua R-2 1116-1326, Chácaras Califórnia, Goiânia, GO 74691-886.

${ }^{7}$ Laboratório de Diagnóstico Patológico Veterinário (LDPV), Universidade de Brasília (UnB), SRB, Área Especial, Galpão 04, Granja do Torto, Brasília, DF 70636-020. *Corresponding author: santanafjf@yahoo.com
}

o período de março de 2010 a agosto de 2017, analisando amostras de três laboratórios de diagnóstico veterinário. De 407 bovinos que apresentaram sinais clínicos neurológicos, o diagnóstico foi estabelecido em 170 casos. Desses casos, foram pesquisadas nas fichas as características epidemiológicas, clínicas e anatomopatológicas. As principais doenças diagnosticadas foram causadas por vírus (raiva 29,41\%, meningoencefalite por herpesvírus bovino $15,88 \%$ e febre catarral maligna $1,76 \%$ ), de origem metabólica (polioencefalomalacia 17,06\%), por bactérias (botulismo 5,88\%, meningite supurativa $3,53 \%$, abscessos encefálicos 2,94\%, listeriose 1,76\% e meningoencefalite trombótica $1,76 \%$ ), sem causa definida (meningoencefalite linfoplasmocítica 11,18\%, hemorragias traumáticas 3,53\% e malacia multifocal com gliose 1,18\%), congênitas (hidrocefalia 1,18\% e malformações múltiplas 0,59\%), tóxicas (intoxicação por ureia 1,18\% e intoxicação por inseticida 0,59\%), e parasitária (meningoencefalite associada à infecção por Trypanosoma sp. 0,59\%).

TERMOS DE INDEXAÇÃO: Doenças neurológicas, Goiás, doenças de bovinos, neuropatologia, raiva, polioencefalomalacia, herpesvírus bovino, neurologia, patologia. 


\section{INTRODUCTION}

Among the several diseases that affect cattle in Brazil, nervous system (NS) disorders are highlighted due to their high frequency and mortality rates. The disorders of the NS in cattle include a group of economically important diseases that present viral, bacterial, toxic, circulatory, metabolic, congenital and neoplastic causes (Barros et al. 2006). In Brazil, it is estimated that rabies causes the death of 40-50 thousand head of cattle per year, resulting in significant economic losses (Reis et al. 2003), and this disease accounts for much of the annual loss of millions of dollars in cattle worldwide (King \& Turner 1993).

In Europe, the importance of diagnosing these neurological disorders has increased dramatically since the 1980s, especially because of the emergence of bovine spongiform encephalopathy (BSE) (Wells et al. 1987). The association of BSE with the human variant of Creutzfeldt-Jakob disease, initially in the United Kingdom, has further increased the political, social and public health importance of this disease (Almond \& Pattison 1997). In response, international health authorities request beef-producing and exporting countries to prove effective monitoring of this disease in their cattle herds. In this context, countries should be able to identify other diseases affecting the NS of cattle, even in the absence of typical cases of BSE.

In Brazil, diseases that affect the NS, such as rabies, botulism and plant poisoning, are important causes of mortality in cattle (Peixoto 1998). Studies conducted in different Brazilian states and regions indicate that, although similar in some situations, the frequency, epidemiology, and clinical and pathological aspects of these neurological diseases in cattle may vary according to the geographic area assessed (Riet-Correa et al. 1998, Sanches et al. 2000, Galiza et al. 2010, Ribas et al. 2013, Oliveira et al. 2016). However, the specific scientific literature lacks clinical-pathological and epidemiological studies addressing the main neurological disorders that affect cattle in the state of Goiás, which is an important national producer of beef and milk.

This study aimed to describe the epidemiological, clinical and anatomopathological characteristics of the main neurological diseases of cattle diagnosed in the state of Goiás from March 2010 to August 2017.

\section{MATERIALS AND METHODS}

A retrospective study was conducted on neurological diseases diagnosed in cattle in the state of Goiás, Brazil, at the Veterinary Pathology Laboratory (LPV) of the Federal University of Goiás (UFG), Jataí campus (RJ), and at the Veterinary Pathology Diagnostic Laboratory (LDPV) of the University of Brasília (UnB) from January 2010 to August 2017. Many cases were kindly provided by the Laboratory of Veterinary Analysis and Diagnosis (Labvet) of the Agricultural Protection Agency of the State of Goiás (Agrodefesa), which is the official laboratory for the diagnosis of rabies in that state.

All necropsy reports and histopathological exams of cattle from the archives of the two laboratories were revised, and the main characteristics associated with epidemiology, clinical signs, anatomopathological aspects, and diagnosis of each case were retrieved. All bovines with neurological signs, including cases with conclusive and inconclusive diagnosis, were considered in this study. In the reports in which a definitive, consistent diagnosis was not achieved, the epidemiological, clinical-laboratory and anatomopathological findings were assessed in order to establish a morphological diagnosis and a possible cause according to the updated literature.

At necropsy, brain samples were collected in all of the cases, and samples of the spinal cord, Gasser ganglia, rete mirabile carotid, and hypophysis (GRH) were collected in some of the cases. Subsequently, all samples were fixed in $10 \%$ formaldehyde. Additional samples of the telencephalon, thalamus, cerebellum, and spinal cord were sent, refrigerated or frozen, to the Labvet for diagnosis of rabies by direct immunofluorescence (DIF) and biological assay (BA). Samples that tested negative for rabies and were histologically compatible with bovine herpesvirus infection (BoHV-1 or 5) or lymphoplasmacytic meningoencephalitis were submitted to the Laboratory of Veterinary Microbiology of the Federal University of Mato Grosso (UFMT) for diagnosis of BoHV using Polymerase Chain Reaction (PCR) (Blume et al. 2018).

After formalin fixation, transversal sections were made in the brain and spinal cord with intervals of $1-2 \mathrm{~cm}$ for macroscopic assessment. The following parts of the brain were processed for microscopic evaluation: cerebellum; medulla oblongata at the obex; pons with cerebellar peduncle; mesencephalon at the rostral colliculus; thalamus; basal nuclei; hippocampus; frontal, parietal and occipital telencephalon; cervical, thoracic and lumbar spinal cord (when available). All fragments were routinely processed for histopathology, embedded in paraffin, and stained with hematoxylineosin (HE).

Microscopically, the lesions were evaluated and described qualitatively and quantitatively according to Sant'Ana et al. (2009b) and Blume et al. (2018).

\section{RESULTS}

Four-hundred and seven cases of cattle that presented clinical signs compatible with or suspected of neurological disease were assessed. In 170 cases (41.77\%), significant microscopic lesions were found, and the diagnoses were established (Table 1). Of these 170 cases, 48 (28.23\%) were from necropsies performed by the LPV/UFG/RJ and LDPV/UnB or referred to these laboratories by field veterinarians and $122(71.77 \%)$ cases were obtained from the Labvet-Agrodefesa. In 237 cases, no microscopic changes were observed in the central nervous system (CNS) that justified the clinical signs reported in their history, including six cases of intoxication by Palicourea marcgravii, which does not cause morphological lesions in the CNS. Figure 1 illustrates the distribution of cases of neurological disease in cattle in the state of Goiás by mesoregion. The main diseases diagnosed during the study period were rabies, necrotizing meningoencephalitis caused by BoHV, and polioencephalomalacia (PEM). Figure 2 shows the case distribution of these diseases per year.

Results obtained in 80 of the cases were associated with viral infections, with 50 cases of rabies, which was the neurological disease most frequently observed in this study. The age of the animals varied from 30 days to 11 years, and most of them ( 40 out of 50 cases) were between 30 days and three years of age. Table 2 presents the municipalities of the state of Goiás where the cases of rabies were diagnosed. The main clinical signs reported were incoordination, paralysis, permanent decubitus, depression, pedal movements, sialorrhea, opisthotonus, and muscle spasms and tremors. The necropsy reports described macroscopic changes, which 
Table 1. Diagnostics in 170 cattle with clinical neurological signs, from 2010 to 2017, state of Goiás, Brazil

\begin{tabular}{|c|c|c|}
\hline Diagnostics & No. cases & $\%$ \\
\hline \multicolumn{3}{|l|}{ Viral diseases } \\
\hline Bovine rabies & 50 & 29.41 \\
\hline Meningoencephalitis by BoHV & 27 & 15.88 \\
\hline Malignant catarrhal fever & 3 & 1.76 \\
\hline Subtotal & 80 & 47.05 \\
\hline \multicolumn{3}{|l|}{ Metabolical diaseases } \\
\hline Polioencephalomalacia & 29 & 17.06 \\
\hline Subtotal & 29 & 17.06 \\
\hline \multicolumn{3}{|l|}{ Bacterial diseases } \\
\hline Botulism & 10 & 5.88 \\
\hline Suppurative meningitis & 6 & 3.53 \\
\hline Encephalic abscesses & 5 & 2.94 \\
\hline Listeriosis & 3 & 1.76 \\
\hline Thrombotic meningoencephalitis & 3 & 1.76 \\
\hline Subtotal & 27 & 15.87 \\
\hline \multicolumn{3}{|l|}{ Diaseases without cause } \\
\hline Lymphoplasmacytic meningoencephalitis & 19 & 11.18 \\
\hline Traumatic hemorrhages & 6 & 3.53 \\
\hline Multifocal malacia with gliosis & 2 & 1.18 \\
\hline Subtotal & 27 & 15.89 \\
\hline \multicolumn{3}{|l|}{ Congenital diaseases } \\
\hline Hydrocephaly & 2 & 1.18 \\
\hline Multiple malformations & 1 & 0.59 \\
\hline Subtotal & 3 & 1.77 \\
\hline \multicolumn{3}{|l|}{ Toxic diseases } \\
\hline Urea poisoning & 2 & 1.18 \\
\hline Insecticide poisoning & 1 & 0.59 \\
\hline Subtotal & 3 & 1.77 \\
\hline \multicolumn{3}{|l|}{ Parasitic diseases } \\
\hline $\begin{array}{l}\text { Meningoencephalitis associated to infection } \\
\text { by Trypanosoma sp. }\end{array}$ & 1 & 0.59 \\
\hline Subtotal & 1 & 0.59 \\
\hline TOTAL & 170 & 100 \\
\hline
\end{tabular}

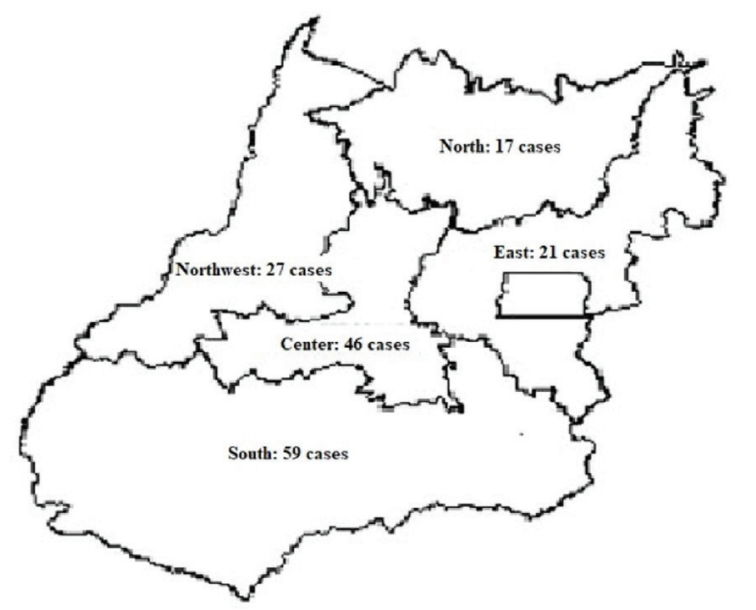

Fig. 1. Map of the state of Goiás, Brazil, with distribution according to mesoregion of 170 cases of neurological diseases diagnosed in cattle from 2010 to 2017.
Table 2. Mesoregion and county distribution of 50 cases of bovine rabies in the state of Goiás, diagnosed by histopathology and direct immunofluorescence and/or biological proof (2010-2017)

\begin{tabular}{lc}
\hline \multicolumn{1}{c}{ Mesoregion and county } & No. cases \\
\hline Center & 6 \\
Caldazinha & 3 \\
Bela Vista de Goiás & 3 \\
Goiânia & 2 \\
Hidrolândia & 1 \\
Itapaci & 1 \\
Itapuranga & 1 \\
Rubiataba & 1 \\
Senador Canedo & 18 \\
Subtotal &
\end{tabular}

South

Caiapônia 2

Jataí 2

Aporé 1

Caçu 1

Cachoeira Dourada 1

Porteirão 1

Quirinópolis 1

Rio Verde 1

Vianópolis 1

Subtotal 11

Northwest

Aragarças $\quad 3$

Britânia 2

Bom jardim de Goiás

Itapirapuã 1

Jussara 1

Piranhas 1

Subtotal 9

North

Uruaçu 3

Niquelândia $\quad 2$

Colinas do Sul 1

Bonópolis 1

Campinaçu 1

Porangatu 1

Subtotal 9

East

Pirenópolis 2

Corumbá de Goiás $\quad 1$

Subtotal 3

Total no. cases $\quad 50$

consisted of reddening of the encephalon leptomeninges with evident vessels, in only three cases. Thirty-four cases of rabies presented lymphoplasmacytic meningoencephalitis associated with intracytoplasmic eosinophilic inclusions in neurons and positive results in DIF and/or BA with intracerebral inoculation of mice (IIM). In ten cases confirmed by DIF/IIM, it was not possible to conclude the diagnosis only by histopathology because there were no inclusion bodies, as well as in six other cases that did not present significant lesions in the 


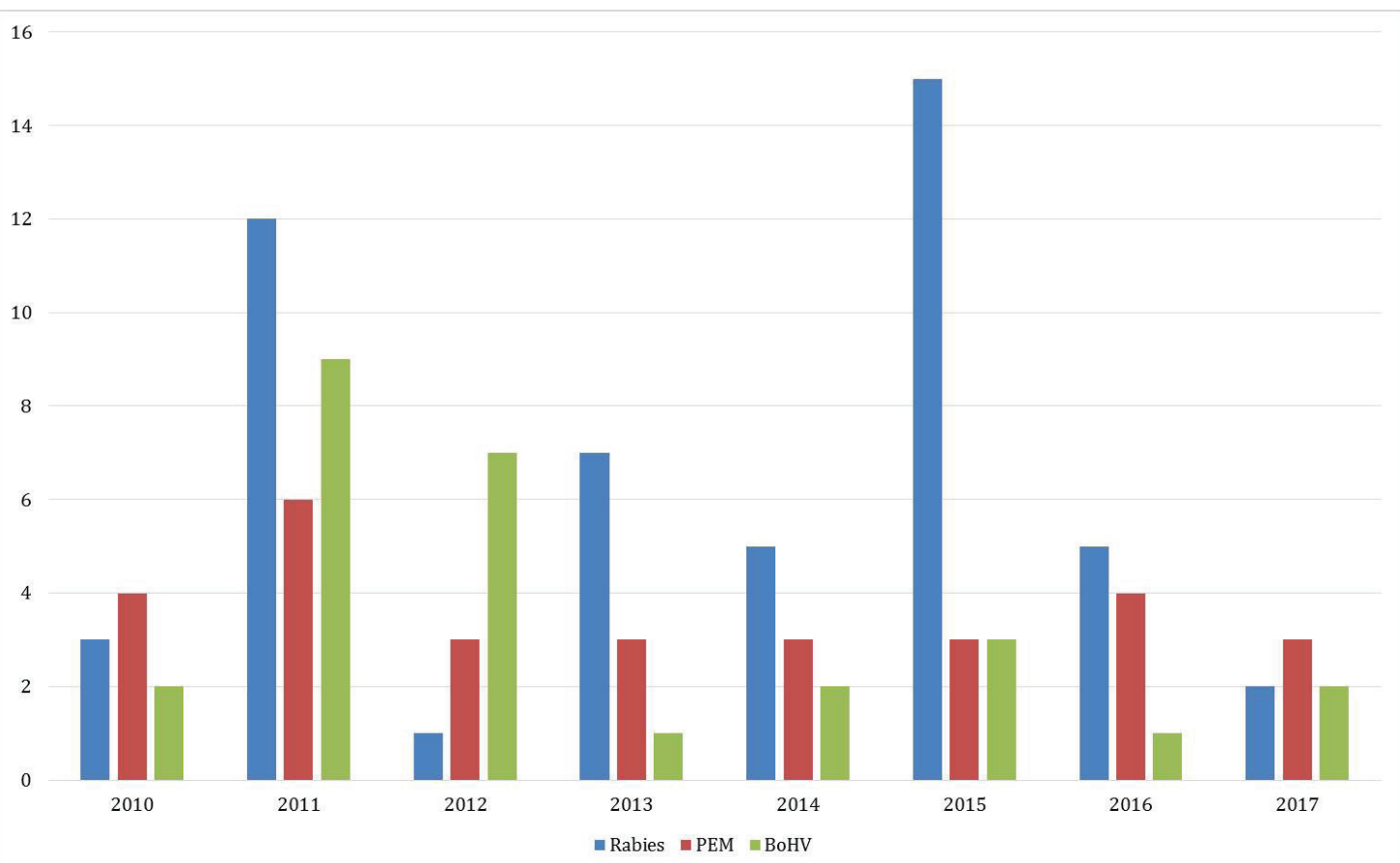

Fig. 2. Distribution per year (2010-2017) of cases of rabies, meningoencephalitis caused by bovine herpesvirus (BoHV), and polioencephalomalacia (PEM) diagnosed in cattle in the state of Goiás, Brazil.

microscopic examination. The histopathological findings were characterized by perivascular cuffs with predominance of lymphocytes, plasma cells and rare macrophages, areas of congestion and hemorrhage, and swelling of the endothelial cells. Multifocal gliosis and occasional neuronophagia were detected in some cases. Inclusion bodies were observed more frequently in neurons in the cerebellum (33/34), pons (21/34), thalamus (16/34), and hippocampus (15/34).

PEM was the second most commonly observed disease, with 29 cases. Age of the affected animals ranged from 30 days to 10 years. The disease affected bovines managed both intensively and extensively with similar frequency. None of the cases presented concrete history information to assist with determining the cause of disease. The main clinical signs reported included blindness, herd withdrawal, apathy, incoordination, paralysis, permanent decubitus, opisthotonus, and pedal movements. Macroscopic lesions were described in six cases and consisted of yellowed, softened and depressed areas in the cortex, whereas slit-like clefts in the gray matter and in the border of that region with the white matter were noted in one case. The main areas of the CNS that presented these lesions were the frontal, parietal and occipital cortex and, less frequently, the thalamus and the basal nuclei. Histologically, the lesions were characterized by segmental and laminar neuronal necrosis; perivascular, perineuronal and neuropilic edema, which occasionally caused slit-like clefts between white and gray matter; swelling of endothelial cells; in some cases, infiltration of Gitter cells, especially in the leptomeninge and in the more superficial neuron layers.

Of the 27 cases of meningoencephalitis caused by BoHV diagnosed, 26 were published recently (Blume et al. 2018). The other case affected an 18-month-old steer in the municipality of Paraúna. Clinical signs were flaccid paralysis of limbs, muscle tremors, aggression and excitability. Microscopic findings included discrete and marked multifocal lymphoplasmacytic-histiocytic necrotizing meningoencephalitis, with edema, endothelial swelling, Gitter cell infiltration, and intranuclear basophilic inclusion bodies in astrocytes.

Nineteen cases presented mononuclear meningoencephalitis (herein called lymphoplasmacytic). These cattle were aged two months to ten years. The clinical signs reported were incoordination, apathy, ataxia, decubitus, pedal movements, and muscle tremors, with clinical evolution to death. There were no reports of macroscopic lesions in these cases. Microscopic findings consisted of a perivascular, multifocal infiltrate, with predominance of lymphocytes and plasma cells, with rare macrophages, especially affecting the neuropils and sometimes extending to the leptomeninges. In addition, multifocal gliosis was observed. All these cases tested negative for rabies in DIF/IIM and for BoHV in PCR.

Ten cases of botulism were diagnosed based on epidemiology, clinical signs, history, and anatomopathological evaluation. Eight cases were associated with osteophagy, probably linked to lack of phosphorus in pasture. Two cases were related to consumption of food contaminated with the toxin: in one of them (1/10), the herd had recently come from another property, where it had been kept in corn and soybean straw and, in the other case $(1 / 10)$, the cattle fed on garbage. Clinical signs were flaccid paralysis of limbs, tail and/or tongue, incoordination, decubitus, and decreased sensitivity. Age of the affected cattle ranged from 16 months to three years. No macroscopic or microscopic lesions were observed in the CNS in any of the cases. 
Suppurative inflammation compatible with bacterial etiology (meningoencephalitis/suppurative meningitis, $6 / 17$ or thrombotic, $3 / 17$; abscesses, 5/17; microabscesses, $3 / 17$ ) was observed in 17 cases. These animals were aged 15 days to four years. No additional tests were performed to determine the etiological agents involved in these suppurative cases. The clinical signs varied according to the anatomical location and extension of the abscess, but consisted of incoordination, blindness, gait alteration, hypermetria, apathy, paralysis, ataxia, muscle spasms, hypotonia, decreased sensitivity, and decubitus. In the cases of meningoencephalitis/suppurative meningitis, the microscopic findings consisted of neutrophil, plasma cell and lymphocyte infiltrates affecting the brain and the meninges. At times, neuronal necrosis, perivascular cuffs, spongiosis, marked Gitter cell infiltrate, axonal spheroids, and gliosis were observed. Three cases of thrombotic meningoencephalitis were observed. In addition to the findings previously described, there were numerous thrombi rich in basophilic coccoid bacteria surrounded by marked infiltrate of neutrophils, lymphocytes, plasma cells and, sometimes, Gitter cells. Focally extensive areas of necrosis enveloped by thin capsule were also observed. Five cases of abscess were diagnosed: three located in the telencephalon, one in the lumbar spinal cord, and one in the cerebellum. Microscopic findings included a focally extensive area of liquefactive necrosis with marked infiltrate of intact and degenerate neutrophils and Gitter cells delimited by a thin capsule. In the areas adjacent to the abscess, marked astrocytosis was associated with compression of the adjacent parenchyma. Edema, neuronal necrosis, and perivascular cuffs were also noted less frequently. In the abscess located in the spinal cord, a moderate number of axonal spheroids were observed.

In addition, microscopic lesions compatible with listeriosis were observed in three cases, and Listeria monocytogenes was isolated from cerebrospinal fluid in one of them. The affected cattle were aged 13 months to four years. The main clinical signs observed were facial paralysis, muscle tremors, aggression, depression, pedal movements, and sialorrhea. No macroscopic lesion was reported. Microscopic findings included multifocal microabscesses in the brainstem, especially in the medulla oblongata, composed of intact and degenerate neutrophils, as well as numerous perivascular cuffs formed by lymphocytes and macrophages, gliosis, several axonal spheroids, and multifocal chromatolysis.

Three cases of bovine malignant catarrhal fever (BMCF) were diagnosed. No description of significant macroscopic findings was found in the necropsy reports. The animals were aged four months to four years. In one case, cattle were raised together with sheep. This information was not available for the other two cases. The following clinical signs were observed: incoordination, nasal bleeding, anorexia, anemia, prostration, and apathy. Microscopically, infiltration of lymphocytes and plasma cells affecting the perivascular space and vessel wall in the CNS was observed, especially in the tunica adventitia and tunica media, and eventually in the tunica intima. These vascular lesions were conspicuous in the rete mirabile carotid.

There was a case of encephalitis associated with infection by Trypanosoma sp. The animal was five years old and was raised in feedlot. The main clinical signs observed were pale mucous membranes, incoordination, aural ptosis, bruises, and apathy. Microscopic findings comprised multifocal perivascular cuffs composed of lymphocytes, plasma cells, and macrophages, as well as multifocal gliosis and areas of hemorrhage. Such lesions were localized in the frontal and parietal cortex, thalamus, basal nuclei, and cerebellum. This case tested negative for rabies in DIF/IIM and for BoHV in PCR. In blood smear, protozoa morphologically compatible with Trypanosoma sp. were observed.

Other infrequent diagnoses included urea intoxication (two cases), hydrocephalus (two cases), multifocal malaise with gliosis (two cases), insecticide intoxication (one case), and multiple congenital malformations (one case). The last case was recently published (Silva et al. 2016); the steer presented cerebellar hypoplasia, stenosis of the mesencephalic aqueduct, fusion of rostral and caudal colliculi, secondary hydrocephalus, villous choroid plexus hypertrophy, and heterotopia of cerebellar cellular constituents. Multiple hemorrhages in various regions of the brain were observed in six animals that had natural death; the cause of these lesions was attributed to trauma.

\section{DISCUSSION}

Neurological diseases are important causes of death of cattle in several regions of Brazil, such as in the northeastern semi-arid region (Galiza et al. 2010) and in the states of Rio Grande do Sul (Riet-Correa et al. 1998, Sanches et al. 2000), Minas Gerais (Oliveira et al. 2016), and Mato Grosso do Sul (Ribas et al. 2013). Data of the present study indicate that rabies, meningoencephalitis caused by BoHV, and PEM are the most common neurological diseases affecting cattle in the state of Goiás. These three diseases accounted for $62.35 \%$ of all the conducted diagnoses. It is worth mentioning that these data refer to the diagnoses performed by diagnostic laboratories in the region and that, occasionally, other cases of neurological diseases have occurred, but were not sent for laboratory diagnosis. In Minas Gerais state, cases of infection with BoHV, PEM, and suppurative encephalitis/meningoencephalitis were the main diseases to be considered in the differential diagnosis for rabies (Oliveira et al. 2016). In the northeast region, rabies corresponds to approximately $50 \%$ of the bovine neurological cases (Galiza et al. 2010). Neurological diseases caused by viruses were the most prevalent in other studies (Sanches et al. 2000, Galiza et al. 2010), corroborating the findings of this survey. Another research conducted in the central-west region indicated botulism, rabies, PEM, infection by BoHV, and nonsuppurative meningoencephalitis (herein called lymphoplasmacytic) as the neurological diseases most commonly observed in cattle (Ribas et al. 2013).

Results of the present study show that approximately $62 \%$ of the neurological cases were diagnosed in the south and central-west mesoregions, probably due to the proximity of the municipalities of these regions to two of the local laboratories that received most of the CNS samples (Labvet and LPV/UFG/RJ). Based on the Normative Instruction (NI) no. 1 of 2005, Agrodefesa establishes the municipalities of Goiás state that present high and low risk of cases of rabies. The municipalities of Uruaçu, Caiapônia, Pirenópolis, and Niquelândia presented the highest numbers of cases of rabies in this study. However, many cases of this disease were reported in municipalities considered of low risk, such as Caldazinha, Bela Vista de Goiás, Hidrolândia, Aragarças, Britânia, and Jataí. Considering that Agrodefesa updates the NI periodically based on the official 
diagnoses performed by the agency, it is possible that other municipalities will be included in the category of high risk in the next edition this document.

Regarding the time distribution of diagnosed cases of the present study, a larger number of cases were observed from 2011 to 2013. In the other years evaluated, the number of cases reported was more uniform; the precise reason for this fact could not be determined. Relatively uniform distribution was also found with respect to the frequency of the most common diseases of this study during the period assessed, except for rabies, which presented a larger number of cases in 2011 and 2015. It is known that seasonality of this disease is associated with the number of infected bats present in the region. Once bats are infected, there is dissemination in the colony and death of individuals. For this reason, cases increase at endemic sites every average period of six to seven years (Mori et al. 2004).

Rabies was the neurological disease with the largest number of cases in this study, corroborating the results of other similar investigations conducted in Brazil (Sanches et al. 2000, Galiza et al. 2010). In cases where it was not possible to confirm the diagnosis of the disease by histopathology, the use of DIF and IIM was conclusive for this purpose, highlighting the importance of these more sensitive and specific techniques for a definitive diagnosis (Langohr et al. 2003, Teixeira et al. 2008, Galiza et al. 2010). Non-visualization of inclusion bodies in some cases of rabies may be directly associated with the survival time of the animal after infection (i.e., the longer the clinical course, the greater the probability of detection of the bodies), the presence of perivascular mononuclear infiltrate, and the absence of or small degenerative change observed in neurons with Negri bodies (Langohr et al. 2003). In five cases of this study, no significant microscopic changes were observed, but they were positive in DIF and IIM. The main histopathological finding in rabies is lymphoplasmacytic meningoencephalitis associated with Negri bodies (Sanches et al. 2000, Langohr et al. 2003, Ribas et al. 2013). According to Pedroso et al. (2008), inclusion bodies can be more easily visualized in Purkinje cells - a fact also observed in the present study. Histopathological findings were more frequent in the cerebellum, pons, thalamus and hippocampus. In another investigation, these findings were more pronounced in the spinal cord and brainstem (Ribas et al. 2013). In addition to the clinical signs reported in this research, sialorrhea, incoordination, muscle tremors, opisthotonus, paralysis, and decubitus have also been observed by other authors (Sanches et al. 2000, Galiza et al. 2010, Ribas et al. 2013). Age of the affected animals varied widely, but most of them were between 30 days and three years old. Very similar retrospective data were observed in southern Brazil (Langohr et al. 2003).

Lesions characterized by neuronal necrosis, edema, and endothelial swelling are the main histological findings in cases of PEM (Sant'Ana et al. 2009a, 2009b). These changes were consistent in all cases of the present study. In addition, there were Gitter cell infiltration and slit-like clefts in cases with more advanced lesions. The main areas of the brain that presented these lesions were the frontal, parietal and occipital telencephalons and, less frequently, the thalamus and basal ganglia, as reported by other authors (Sant'Ana et al. 2009b, Nogueira et al. 2010, Cunha et al. 2011). In one case of the present study, histological findings and epidemiology were suggestive of PEM associated with salt/water deprivation intoxication. In the other cases, lack of history information prevented the cause of the disease from being inferred and determined, as it occurs in most of the domestic descriptions of this disease (Sant'Ana \& Barros 2010). It is known that the etiopathogenesis of this disease is not completely understood, but many factors can be determinant in the emergence of cases, such as thiamine deficiency, poisoning with sulfur, amprolium or lead, and abrupt changes in diet (Sant'Ana et al. 2009a, Cunha et al. 2011, Nogueira et al. 2010). The following major clinical signs were observed in the present study: depression, incoordination, paralysis, blindness, permanent decubitus, opisthotonus, and pedal movements. Nogueira et al. (2010) also observed other clinical signs in cases of PEM, such as strabismus, nystagmus, mydriasis, and frequent falls. Blindness is one of the clinical signs most consistent with this disease and commonly reported by several authors, and it was also observed in this study (Sant'Ana et al. 2009b, Nogueira et al. 2010, Cunha et al. 2011, Ribas et al. 2013).

Meningoencephalitis caused by BoHV occurred mainly in young cattle, evenly during the study period, and more often in the south and central-west mesoregions (Blume et al. 2018). Similar data were obtained in other investigations (Rissi et al. 2006, Massitel et al. 2016). The clinical signs presented by the bovines of this study were similar to those reported in other descriptions of bovine herpetic meningoencephalitis (Ely et al. 1996, Colodel et al. 2002, Elias et al. 2004, Lemos 2005, Rissi \& Barros 2013), and included blindness, incoordination, sialorrhea, and ataxia. The most frequently observed macroscopic changes were congestion with swelling and flattening of the convolutions, softening and yellow discoloration of the telencephalic cortex, and hemorrhagic foci, as previously reported (Colodel et al. 2002, Elias et al. 2004, Riet-Correa et al. 2006, Rissi \& Barros 2013). Histological changes occurred uniformly throughout the brain and consisted of lymphoplasmacytic meningoencephalitis, intranuclear basophilic inclusion bodies in astrocytes and neurons, neuronal necrosis, edema, endothelial swelling, gliosis, astrocytosis, Gitter cell infiltration, congestion, and hemorrhage. These findings are similar to those observed by other authors (Colodel et al. 2002, Elias et al. 2004, Riet-Correa et al. 2006, Rissi et al. 2006, Freitas Neto et al. 2010, Pedraza et al. 2010, Rissi \& Barros 2013, Oliveira et al. 2016). DNA of the BoHV-5 was amplified in two cases, whereas DNA of the BoHV-1 was identified in one case. For the first time, BoHV-1 was confirmed as a cause of meningoencephalitis in the central-west region of Brazil (Blume et al. 2018), although it had already been detected in the south region (Riet-Correa et al. 1989, Silva et al. 2007, Rissi et al. 2008, Rissi \& Barros 2013).

All cases included in the category lymphoplasmacytic meningoencephalitis tested negative for rabies in DIF and IIM and for BoHV infection in PCR. Although these cases are suggestive of viral infection, no inclusion bodies, neuronal necrosis, or vasculitis were observed in any of them, thus impeding exact determination of the etiologic agent. Cases with identical or similar morphological and laboratory characteristics have been reported in other regions of Brazil (Lemos et al. 2005, Galiza et al. 2010, Ribas et al. 2013), alerting veterinarians and researchers for possible new pathogens circulating in 
national herds or for an eventual change in the morphologic pattern of certain infections.

In the ten cases of botulism evaluated in this study, the diagnosis was made based on epidemiological and clinical findings and in the absence of significant macroscopic and microscopic lesions. The main factors associated with the outbreak of botulism regard phosphorus deficiency, access to abandoned carcasses in pastures, provision of human food waste, and supply of chicken litter (Câmara et al. 2014), toxin-contaminated water (Dutra et al. 2001), and improperly conserved food (Maboni et al. 2010). A common practice, especially in the northwest of the states of Goiás and Mato Grosso, is the provision of water to animals in contaminated water holes - a fact that has been commonly associated with emergence of disease outbreaks (Souza et al. 2011). Frequency of this disease might be higher in the state of Goiás, because the clinical and epidemiological characterization is essential for its diagnosis (Lemos \& Leal 2008) and these data often were not adequately present in the case histories evaluated in the present survey. Another factor to be considered is that many cattle that did not present any histopathological lesion, and thus did not have a complete diagnosis, presented the clinical sign of flaccid paralysis but were alert. It is possible that some of these cases are attributed to botulism and have not been correctly diagnosed. In this study, the main factor involved in the pathogenesis of the disease was osteophagy; however, one case was associated with previous ingestion of corn and soybean straw, as described by other authors in Mato Grosso do Sul state (Lemos \& Leal 2008). These data are consistent with those found in other studies (Dutra et al. 2001, Ribas et al. 2013).

Bacterial inflammations were characterized by suppurative/thrombotic meningoencephalitis or formation of abscess or microabscess. Cases of thrombotic meningoencephalitis in cattle are commonly associated with infection by Histophilus somni (Barros et al. 2006, Galiza et al. 2010). In the present research, it was not possible to confirm the etiology of the cases of this change using microbiological techniques; however, the histological lesions were suggestive of infection by H. somni. The route of infection by these bacterial agents usually occurs because of oral trauma associated with foreign bodies (Galiza et al. 2010), omphalophlebitis (Assis-Brasil et al. 2013, Ribas et al. 2013), use of nasal plastic device for discontinuation of weaning (Loretti et al. 2003, Câmara et al. 2009), pneumonia, and rhinitis (Câmara et al. 2009). Clinical signs of these bacterial neuropathies included incoordination, blindness, gait alteration, hypermetria, depression, paralysis, ataxia, muscle spasms, hypotonia, decreased sensitivity, and decubitus. The age of the animals ranged from 15 days to four years. According to some authors, brain abscesses are diagnosed more frequently in young cattle (Barros et al. 2006, Helayel et al. 2014). Three cases of listeriosis were diagnosed. The diagnosis was based on histological findings characteristic of microabscesses in the brainstem (Sanches et al. 2000, Galiza et al. 2010, Oliveira et al. 2016).

Three cases of BMCF were diagnosed in this study. This disease has also been diagnosed in other areas of Brazil, especially in the northeast and south regions, apparently with higher frequency (Sanches et al. 2000, Rech et al. 2005, Macêdo et al. 2007, Galiza et al. 2010), and there are also reports in the states of São Paulo and Mato Grosso do Sul (Lemos et al. 2005), and Minas Gerais (Oliveira et al. 2016). This fact is probably associated with the higher occurrence of sheep rasing in these latter regions. Moreover, in many cases of this study, the material received for histopathology did not contain the heterogenous tissue GRH complex, which is extremely important for the histopathological diagnosis of this disease (Rech et al. 2006). BMCF is histologically characterized by vasculitis with fibrinoid necrosis in several organs (Garmatz et al. 2004, Furlan et al. 2012, Oliveira et al. 2016), as observed in the present study. The clinical signs observed were incoordination, nasal bleeding, anorexia, anemia, prostration, and apathy. Other authors have reported corneal opacity, conjunctivitis, salivation, mucosal erosions, and hematuria as clinical signs of this disease (Garmatz et al. 2004). Although macroscopic findings in the brain are common in cases of BMCF (Barros et al. 2006), these changes were not available in the necropsy reports evaluated in the present study.

In the case of meningoencephalitis by Trypanosoma sp., the microscopic findings were characterized by multifocal perivascular cuffs composed of lymphocytes, plasma cells, and macrophages, as well as gliosis and focal areas of hemorrhage affecting the frontal and parietal telencephalon, thalamus, basal nuclei, and cerebellum. The findings of this study were similar to those of a previous research, with the parietal, occipital and temporal cortex and the cerebellum as the main regions of the brain affected, and the diagnosis was confirmed by observation of the agent in leukocyte-layer smears and in subsequent PCR (Batista et al. 2008). The major clinical signs were incoordination, atrial ptosis, bruises, and apathy. In addition to the clinical signs reported in this study, Batista et al. (2008) also observed salivation, opisthotonus, nystagmus, tetany seizure, and bruxism.

Two cases of urea intoxication were diagnosed. The diagnosis was made based on history of recent and excessive supply of urea without previous food adaptation, on the clinical signs presented by the animals, and on the absence of significant macroscopic and microscopic changes. The diagnosis of intoxication with insecticide was conducted based on clinical signs, recent application of organophosphorus insecticides in fields adjacent to the pasture that the cattle were grazing, as well as on scarcity of significant changes. Similar cases have been reported in Rio Grande do Sul state (Oliveira Filho et al. 2010, Santos et al. 2014).

A rare case of multiple congenital abnormalities in the brain was diagnosed in a recently published study (Silva et al. 2016). Several significant changes were detected, namely, cerebellar hypoplasia, stenosis of the mesencephalic aqueduct, fusion of the rostral and caudal colliculi, secondary hydrocephalus, villous choroid plexus hypertrophy, and heterotopia of cerebellar cellular constituents. Similar conditions had never been observed in the property, and it is not possible to define the precise cause of this condition. Negative immunohistochemistry (IHC) for bovine viral diarrhea performed on the brainstem samples of this steer suggests that this agent was not involved in the etiopathogenesis of these lesions.

\section{CONCLUSIONS}

The main neurological diseases diagnosed in cattle in the state of Goiás were rabies, polioencephalomalacia, and BoHV infection.

Histological lesions compatible with bovine spongiform encephalopathy were not observed in any of the cases assessed in the present study. This information is important 
for the maintenance of the sanitary status of the state of Goiás regarding this disease.

Acknowledgements.- The authors are grateful to CNPq for the grant given to the first author and to the laboratories that provided the samples and information to conduct this study, especially to Labvet/Agrodefesa.

\section{REFERENCES}

Almond J. \& Pattison J. 1997. Human BSE. Nature 389(6650):437-438. <http://dx.doi.org/10.1038/38876><PMid:9333228>

Assis-Brasil N.D., Marcolongo-Pereira C., Hinnah F.L., Ladeira S.R.L., Sallis E.S.V., Grecco F.B. \& Schild A.L. 2013. Enfermidades diagnosticadas em bezerros na região sul do Rio Grande do Sul. Pesq. Vet. Bras. 33(4):423-430. <http://dx.doi.org/10.1590/S0100-736X2013000400002>

Barros C.S.L., Driemeier D., Dutra I.S. \& Lemos R.A.A. 2006. Doenças do Sistema Nervoso de Bovinos no Brasil. Agnes, São Paulo, p.166-171.

Batista J.S., Bezerra F.S.B.B., Lira R.A., Carvalho J.R.G., Rosado Neto A.M., Petri A.A. \& Teixeira M.G. 2008. Aspectos clínicos, epidemiológicos e patológicos da infecção natural em bovinos por Trypanosoma vivax na Paraíba. Pesq. Vet. Bras. 28(1):63-69. <http://dx.doi.org/10.1590/S0100736X2008000100010>

Blume G.R., Silva L.F., Borges J.R.J., Nakazato L., Terra J.P., Rabelo R.E., Vulcani V.A.S. \& Sant'Ana F.J.F. 2018. Caracterização etiológica, epidemiológica e clínico-patológica da meningoencefalite por herpesvírus bovino em bovinos no Estado de Goiás. Pesq. Vet. Bras. 38(5):902-912. <http://dx.doi. org/10.1590/1678-5150-pvb-5341>

Câmara A.C.L., Oliveira C.M.D.M., Vale A.M.D., Batista J.S. \& Soto-Blanco B. 2014. Epidemiology, clinical signs, laboratorial and pathological findings in eight outbreaks of botulism in cattle in Rio Grande do Norte state. Northeastern Brazil. Acta Scient. Vet. 42:1200.

Câmara A.C.L., Borges J.R.J., Godoy R.F., Moscardini A.R.C., Mustafa V.S., Castro M.B., Ximenes F.H.B., Paludo G.R., Perecmanis S. \& Drummond V.O. 2009. Pituitary abscess syndrome in calves from Mid-Western Brazil. Pesq. Vet. Bras. 29:925-930.

Colodel E.M., Nakazato L., Weiblen R., Mello R.M., Silva R.R.P., Souza M.A., Oliveira Filho J.A. \& Caron L. 2002. Meningoencefalite necrosante em bovinos causada por herpesvírus bovino no estado de Mato Grosso do Sul, Brasil. Ciência Rural 32(2):293-298. <http://dx.doi.org/10.1590/ S0103-84782002000200018>

Cunha P.H.J., Badial P.R., Cagnini D.Q., Oliveira-Filho J.P., Moares L.F., Takahira R.K., Amorim R.L. \& Borges A.S. 2011. Polioencefalomalácia experimental em bovinos induzida por toxicose por enxofre. Pesq. Vet. Bras. 31(1):41-52. <http://dx.doi.org/10.1590/S0100-736X2011000100007>

Dutra I.S., Döbereiner J., Rosa I.V., Souza L.A.A. \& Nonato M. 2001. Surtos de botulismo em bovinos no Brasil associados à ingestão de água contaminada. Pesq. Vet. Bras. 21(2):43-48. <http://dx.doi.org/10.1590/ S0100-736X2001000200002>

Elias F., Schild A.L. \& Riet-Correa F. 2004. Meningoencefalite e encefalomalacia por herpesvírus bovino-5: distribuição das lesões no sistema nervoso central de bovinos naturalmente infectados. Pesq. Vet. Bras. 24(3):123-131. <http://dx.doi.org/10.1590/S0100-736X2004000300003>

Ely R.W., D’Offay J.M., Ruefer A.H. \& Cash C.Y. 1996. Bovine herpesviral encephalitis: a retrospective study on archived formalin-fixed, paraffinembedded brain tissue. J. Vet. Diagn. Invest. 8(4):487-492.<http://dx.doi. org/10.1177/104063879600800416> <PMid:8953538>

Freitas Neto A.P., Bannwart L.F., Verdejo A.C.F., Rabelo R.E., Garcia E.C. \& Sant'Ana F.J.F. 2010. Meningoencefalite por herpesvírus bovino no Sudoeste de Goiás. Revta Interbio 4(1):146.

Furlan F.H., Amorim T.M., Justo R.V., Mendes E.R.S., Zilio M.G., Costa F.B., Nakazato L. \& Colodel E.M. 2012. Malignant catarrhal fever in cattle in the Northern Region of Mato Grosso, Brazil. Acta. Scient. Vet. 40:1-4.
Galiza G.J.N., Silva M.L.C.R., Dantas A.F.M., Simões S.V.D. \& Riet-Correa F. 2010. Doenças do sistema nervoso de bovinos no semiárido nordestino. Pesq. Vet. Bras. 30(3):267-276. <http://dx.doi.org/10.1590/S0100736X2010000300014>

Garmatz S.L., Irigoyen L.F., Rech R.R., Brown C.C., Zhang J. \& Barros C.S.L. 2004. Febre catarral maligna em bovinos no Rio Grande do Sul: transmissão experimental para bovinos e caracterização do agente etiológico. Pesq. Vet. Bras. 31:41-52.

Helayel M.A., Ramos A.T., Viana E.B., Baptista F., Burns L.V., Moron S.E., Palomaris D., Souza M. \& Barbosa F.B. 2014. Aspectos clínico-patológicos, microbiológicos e hematológicos de abscesso cerebral em bovinos: relato de caso. Revta Bras. Med. Vet. 36:1-5.

King A.A. \& Turner G.S. 1993. Rabies: a review. J. Comp. Pathol. 108(1):1-39. <http://dx.doi.org/10.1016/S0021-9975(08)80224-1><PMid:8473555>

Langohr I.M., Irigoyen L.F., Lemos R.A.A. \& Barros C.S.L. 2003. Aspectos epidemiológicos, clínicos e distribuição das lesões histológicas no encéfalo de bovinos com raiva. Ciência Rural 33(1):125-131. <http://dx.doi. org/10.1590/S0103-84782003000100020>

Lemos R.A.A. 2005. Enfermidades do sistema nervoso de bovinos de corte das regiões Centro-Oeste e Sudeste do Brasil. Tese de Doutorado, Universidade Estadual Paulista, Jaboticabal, São Paulo. 150p.

Lemos R.A.A. \& Leal C.R.B. 2008. Doenças de Impacto Econômico em Bovinos de Corte: perguntas e respostas. UFMS, Campo Grande, MS, p.41-64.

Lemos R.A.A., Rech R.R., Guimarães E.B., Kadri A. \& Dutra I.S. 2005. Febre catarral maligna em bovinos do Mato Grosso do Sul e de São Paulo. Ciência Rural 35(4):932-934. <http://dx.doi.org/10.1590/S0103-84782005000400030>

Loretti A.P., Ilha M.R.S., Riet-Correa G., Driemeier D., Colodel E.M. \& Barros C.S.L. 2003. Síndrome do abscesso pituitário em bezerros associada ao uso de tabuleta nasal para desmame interrompido. Pesq. Vet. Bras. 23(1):39-46. <http://dx.doi.org/10.1590/S0100-736X2003000100007>

Maboni F., Monego F., Matiuzzi da Costa M., Dutra I. \& Palmira Castagna de Vargas A. 2010. Occurrence of botulism in feedlot bovine in Rio Grande do Sul State. Ciênc. Anim. Bras. 11:962-965. <http://dx.doi.org/10.5216/ cab.v11i4.3336>

Macêdo J.T.S.A., Riet-Correa F., Simões S.V.D., Dantas A.F.M. \& Nobre V.M.T. 2007. Febre catarral maligna em bovinos na Paraíba. Pesq. Vet. Bras. 27(7):277-281. <http://dx.doi.org/10.1590/S0100-736X2007000700004>

Massitel J.L., Wesgueber J., Oliveira R.A.M., Queiroz G.R., Fritzen J.T.T., Alfieri A.A. \& Lisbôa J.A.N. 2016. Presença do genoma de BoHV-5 no líquido cefalorraquidiano de bovinos com meningoencefalite herpética. Arq. Bras. Med. Vet. Zootec. 68(2):548-552.<http://dx.doi.org/10.1590/16784162-8087>

Mori A.E., Lemos R.A.A. \& Kadri A. 2004. Raiva, p.63-86. In: Lemos R.A.A. (Ed.), Série Qualificação Rural. Vol.2. UFMS, Mato Grosso do Sul.

Nogueira A.P.A., Souza R.I.C., Santos B.S., Pinto A.P., Ribas N.L.K.S., Lemos R.A.A. \& Sant'Ana F.J.F. 2010. Polioencefalomalacia experimental induzida por amprólio em bovinos. Pesq. Vet. Bras. 30(8):631-636. <http://dx.doi. org/10.1590/S0100-736X2010000800004>

Oliveira T.S., Bull V., Furtini R., Drummnond S.R.M., Costa E.A., Santos R.L. \& Paixão T.A. 2016. Neurological diseases of cattle diagnosed through histopathology in Minas Gerais. Braz. J. Vet. Pathol. 9:62-69.

Oliveira-Filho J.C., Carmo P.M.S., Pierezan F., Tochetto C., Lucena R.B., Rissi D.R. \& Barros C.S.L. 2010. Intoxicação por organofosforados no Rio Grande do Sul. Pesq. Vet. Bras. 30(10):803-806. <http://dx.doi.org/10.1590/ S0100-736X2010001000001>

Pedraza F.J., Alessi A.C. \& Barbosa-Stancioli E.F. 2010. Detection of bovine herpesvirus 5 (BoHV-5) in formalin-fixed, paraffin-embedded bovine brain by nested PCR in Colombian cattle. Revta Colom. Cienc. Pecuarias 23:292-298. 
Pedroso P.M.O., Pescador C.A., Bandarra P.M., Raymundo D.L., Borba M.R., Wouters F., Bezerra Júnior P.S. \& Driemeier D. 2008. Padronização da técnica de imuno-histoquímica para raiva em amostras de tecido do sistema nervoso central de bovinos fixadas em formol e emblocadas em parafina. Pesq. Vet. Bras. 28(12):627-632. <http://dx.doi.org/10.1590/ S0100-736X2008001200012>

Peixoto P.V. 1998. Raiva bovina e linhas de conduta. Pesq. Vet. Bras. 18(1):4546. <http://dx.doi.org/10.1590/S0100-736X1998000100008>

Rech R.R., Rissi D.R., Silva M.C., Inkelmann A. \& Barros C.S.L. 2006. Histomorfologia do gânglio de Gässer, da rete mirabile carotídea e da hipófise de bovinos: estudo de 199 casos. Pesq. Vet. Bras. 26(2):105-111. <http://dx.doi.org/10.1590/S0100-736X2006000200008>

Rech R.R., Schild A.L., Driemeier D., Garmatz S.L., Oliveira F.N., Riet-Correa F. \& Barros C.S.L. 2005. Febre catarral maligna em bovinos no Rio Grande do Sul: epidemiologia, sinais clínicos e patologia. Pesq. Vet. Bras. 25(2):97-105. <http://dx.doi.org/10.1590/S0100-736X2005000200006>

Reis M.C., Costa J.N., Peixoto A.P.C., Figueiredo L.J.C., Menezes R.V., Ferreira M.M. \& Sá J.E.U. 2003. Aspectos clínicos e epidemiológicos da raiva bovina apresentados na casuística da Clínica de Bovinos (Oliveira dos Campinhos, Santo Amaro, Bahia), Universidade Federal da Bahia, durante o período de janeiro de 1990 a dezembro de 1999 (Relato de caso). Revta Bras. Saúde. Prod. Anim. 4:12-17

Ribas N.L.K.S., Carvalho R.I., Santos A.C., Valençoela R.A., Gouveia A.F., Castro M.B., Mori A.E. \& Lemos R.A.A. 2013. Doenças do sistema nervoso de bovinos no Mato Grosso do Sul: 1082 casos. Pesq. Vet. Bras. 33(10):1183-1194. <http://dx.doi.org/10.1590/S0100-736X2013001000003>

Riet-Correa F., Schild A.L. \& Fernandes C.G. 1998. Doenças do sistema nervoso central dos ruminantes no Rio Grande do Sul. Ciência Rural 28:341-348. <http://dx.doi.org/10.1590/S0103-84781998000200028>

Riet-Correa F., Vidor T., Schild A.L. \& Motta A. 1989. Meningoencefalite e necrose do córtex cerebral em bovinos causadas por Herpesvirus bovino-1. Pesq. Vet. Bras. 9:13-16.

Riet-Correa G., Duarte M.D., Barbosa J.D., Oliveira C.M.C., Cerqueira V.D., Brito M.F. \& Riet-Correa F. 2006. Meningoencefalite e polioencefalomalacia causada por Herpesvírus bovino-5 no Estado do Pará. Pesq. Vet. Bras. 26(1):44-46. <http://dx.doi.org/10.1590/S0100-736X2006000100009>

Rissi D.R. \& Barros C.S. 2013. Necrotizing meningoencephalitis in a cow. Vet. Pathol. 50(5):926-929.<http://dx.doi.org/10.1177/0300985813478209> $<$ PMid:23446433>

Rissi D.R., Pierezan F., Silva M.S., Flores E.F. \& Barros C.S.L. 2008. Neurological disease in cattle in southern Brazil associated with Bovine herpesvirus infection. J. Vet. Diagn. Invest. 20(3):346-349. <http://dx.doi. org/10.1177/104063870802000315><PMid:18460624>
Rissi D.R., Oliveira F.N., Rech R.R., Pierezan F., Lemos R.A.A. \& Barros C.S.L. 2006. Epidemiologia, sinais clínicos e distribuição das lesões encefálicas em bovinos afetados por meningoencefalite por herpesvírus bovino- 5 . Pesq. Vet. Bras. 26(2):123-132. <http://dx.doi.org/10.1590/S0100736X2006000200010>

Sanches A.W.D., Langohr I.M., Stigger A.L. \& Barros C.S.L. 2000. Doenças do sistema nervoso central em bovinos no Sul do Brasil. Pesq. Vet. Bras. 20(3):113-118. <http://dx.doi.org/10.1590/S0100-736X2000000300005>

Sant'Ana F.J.F. \& Barros C.S.L. 2010. Polioencephalomalacia in ruminants in Brazil. Braz. J. Vet. Pathol. 3:70-79.

Sant'Ana F.J.F., Lemos R.A.A., Nogueira A.P.A., Togni M., Tessele B. \& Barros C.S.L. 2009a. Polioencefalomalacia em ruminantes. Pesq. Vet. Bras. 29(9):681694. <http://dx.doi.org/10.1590/S0100-736X2009000900001>

Sant'Ana F.J.F., Rissi D.R., Lucena R.B., Lemos R.A.A., Nogueira A.P.A. \& Barros C.S.L. 2009b. Polioencefalomalacia em bovinos: epidemiologia, sinais clínicos e distribuição das lesões no encéfalo. Pesq. Vet. Bras. 29(7):487497. <http://dx.doi.org/10.1590/S0100-736X2009000700002>

Santos B.L., Marcolongo-Pereira M., Stigger A.L., Coelho A.C.B., Soares M.P., Sallis E.S.V., Barreto F. \& Schild A.L. 2014. Uso inadequado de organ ofosforados: uma prática de risco para bovinos no Sul do Rio Grande do Sul. Pesq. Vet. Bras. 34(7):655-658. <http://dx.doi.org/10.1590/S0100-736X2014000700008>

Silva L.F., Rabelo R.E., Santos G.P., Aguiar O.L.R., Sonne L., Barros C.S.L. \& San'Ana F.J.F. 2016. Multiple congenital encephalic malformations in a calf. Braz. J. Vet. Pathol. 9:103-107.

Silva M.S., Brum M.C.S., Weiblen R. \& Flores E.F. 2007. Identificação e diferenciação de bovino tipos 1 e 5 isolados de amostras clínicas no Centro-Sul do Brasil, Argentina e Uruguai (1987-2006). Pesq. Vet. Bras. 27(10):403-408. <http://dx.doi.org/10.1590/S0100-736X2007001000003>

Souza A.M., Dias Filho F.C., Dutra I.S., Marques D.F., Silva S.H., Souza J.A., Santos P.M., Godoi W.P. \& Gomes R.O.M. 2011. Ocorrência de Clostridium botulinum tipos $\mathrm{C}$ e D em criatórios de bovinos no município de Cocalinho, Vale do Araguaia, Mato Grosso. IX Congresso Brasileiro Buiatria, Goiânia, GO. Vet. Zootec., Botucatu, 18:831-34.

Teixeira T.F., Holz C.L., Caixeta S.P.M.B., Dezen D., Cibulski S.P., Silva J.R., Rosa J.C.A., Schmidt E., Ferreira J.C., Batista H.B.C.R., Caldas E., Franco A.C. \& Roehe P.M. 2008. Diagnóstico de raiva no Rio Grande do Sul, Brasil, de 1985 a 2007. Pesq. Vet. Bras. 28(10):515-520. <http://dx.doi.org/10.1590/ S0100-736X2008001000012>

Wells G.A.H., Scott A.C., Johnson C.T., Gunning R.F., Hancock R.D., Jeffrey M., Dawson M. \& Bradley R. 1987. A novel progressive spongiform encephalopathy in cattle. Vet. Rec. 121(18):419-420. <http://dx.doi. org/10.1136/vr.121.18.419><PMid:3424605> 